\title{
Occurrence of Black Stain on Fruit Skin (Black Spots) in Relation to Growth and Development of Pericarp Tissues in Japanese Persimmons ${ }^{1}$
}

\author{
Hiroshi Yamamura, Hideo Bessho ${ }^{2}$ and Ryuji Naito \\ Faculty of Agriculture, Shimane University, Matsue, Shimane 690
}

\begin{abstract}
Summary
The effect of the growth and development of pericarp tissues on the occurrence of the various types of black stain on fruit skin was examined in Japanese persimmons (Diospyros kaki Thunb.), 'Fuyu' and 'Saijo' to define why 'Saijo' is experientially said to be more susceptible to the disorders than 'Fuyu'.

1. Dotty type occurred most frequently in both cultivars. In 'Saijo', disorders of vertically striped type gave the next higher rate of occurrence, followed by those of vertical line-like and broken line-like types. However, in 'Fuyu', vertical linelike type occurred most often after dotty type, both of which occurred more often than the other types.

2. Broken line-like and cloudy types occurred mainly in the apical and median portions of fruit, while wavy and vertical line-like types were observed mostly in the basal portion in both cutivars.

3. In both cultivars, the rate of growth differed largely with the portions of fruit examined, decreasing successively from the base to the apex.

4. The cuticle layer of fruit in 'Saijo' was thinner than that in 'Fuyu' in the early stage of growth. Also, the development of epidermal and sub-epidermal cells in 'Saijo' was inferior to that in 'Fuyu'.

5. The characteristic disorders in 'Saijo' were vertically striped and broken line-like types. These seem to be the typical ones caused by rapid enlargement of fruit in the late stage accompanied by the expansion of fine splits on the skin.
\end{abstract}

\section{Introduction}

Japanese persimmon is generally susceptible to various types of disorders which appear on the surface of fruit and are collectively called black stain $(2,3,9,11)$. In comparison with 'Hiratanenashi' and 'Fuyu', leading cultivars of astringent and non-astringent persimmons in Japan respectively, 'Saijo', a leading astringent persimmon in Chugoku district is particularly suceptible to the disorders which greatly reduce the marketability of fruits. These disorders have been classified by means of visible symptoms into 5 or 6 types. They are thought to be caused mainly by fine splits on the fruit $\operatorname{skin}(1,9)$, which arise as a result

1 Received for publication April 27, 1984.

2 Present address : Fruit tree research station, Morioka, Iwate 020-01 of the unequal growth of internal and external tissues in the fruit. Since the fruit of 'Saijo' is egg shaped and that of 'Fuyu' is round, the pattern of growth is thought to be different in the two cultivars. The susceptibility to these skin disorders may be related to the differences in growth pattern.

In the present study, 'Saijo' was compared with 'Fuyu' on the growth rates in various portions of fruit surface and the histlogical development of skin tissues.

\section{Materials and Methods}

In 1981, 5 trees each of 19-year-old 'Saijo' and 21-year-old 'Fuyu' were selected at the orchard of Shimane University, Matsue. In this report, the disorders of black stain on fruit skin were classified by means of visible symptoms into 6 types; cloudy, dotty, verti- 

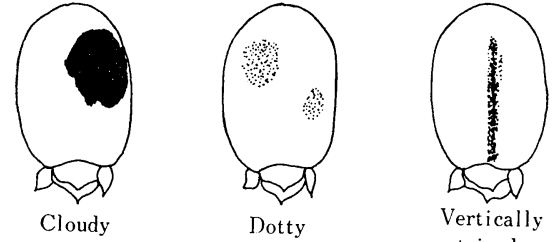
striped

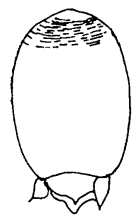

Broken

line-like
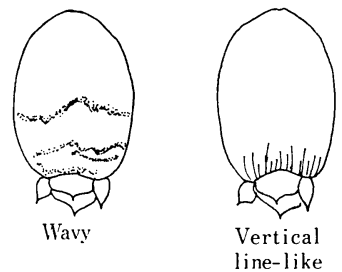

Fig.1. Scheme of 6 types of black stain on fruit skin in 'Saijo'.

cally striped, broken line-like, wavy and vertical line-like types as shown in Fig.1. In order to clarify the time and cause of their occurrence, 50 fruits of each cultivar were visually inspected every 10 days from early August until early September, and every 5 days thereafter until harvest time. The harvest dates of 'Saijo' and 'Fuyu' were Oct. 3 and Nov. 3, respectively. Skin tissues of both cultivars were sampled every 20 days from 10 days after full bloom (June 15). Segments were fixed in a solution of formalin, acetic acid and alcohol (FAA), and then embedded in paraffin after dehydration in an alcohol-buthanol series. Sections of $10 \mu \mathrm{m}$ were cut with a rotary microtome and double-stained with acid fuchsin and fast green. The thickness of cuticle and sub-epidermal cell layer and the radial size of epidermal and sub-epidermal cells were measured.

In order to examine the localized growth of fruit surface, latitudinal lines were marked at $2 \mathrm{~mm}$ intervals from apex to base on the surface of 20 fruits 25 days after full bloom (June 30) using the tip of a needle. The intervals between the lines and the transverse and longitudinal diameters of fruit were measured every 20 days. The localized growth of the fruit surface in the later stage was investigated as follows. A latitudinal line was marked at the base of fruit surface every 20 days from July 20 to harvest, at which time

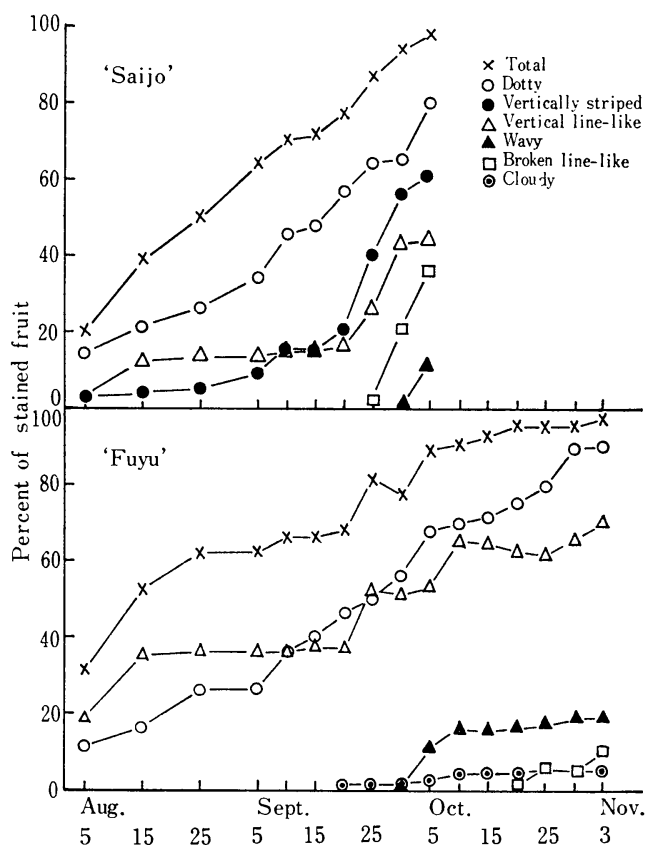

Fig. 2. Time course examination of the occurrence of black stain on fruit skin in 'Saijo' and 'Fuyu'.

the intervals between the lines were measured.

\section{Results}

Fig. 1 shows the symptoms of black stain classified into 6 types. As shown in Fig. 2, dotty and vertical line-like types had already appeared in July in both cultivars while the other types became noticeable in the later stage of fruit growth. Dotty type occurred most often in both cultivars. This type, however, did not markedly down-grade the market value of the fruit. In 'Fuyu' vertical line-like was the second-most frequently occurring type but it appeared mostly around the base of fruit and was not so noticeable. However, in 'Saijo' both vertically striped and broken line-like types followed dotty type in rate of occurrence, and both reduced the marketability of the fruit. The total occurrence rates of all types at harvest reached as much as about $98 \%$ in both cultivars. Although cloudy type reduced the marketability by the greatest degree because of its most conspicuous symptom, it appeared slightly in 'Fuyu' alone in this year. 
Table 1. Position of the occurrence of black stain on fruit surface.

\begin{tabular}{lllll}
\hline \multirow{2}{*}{ Cultivar } & Type of black stain & \multicolumn{3}{c}{$\begin{array}{l}\text { Rate of occurrence in } \\
\text { each position }\end{array}$} \\
\cline { 3 - 5 } & & Apex & Median & Base \\
\hline 'Saijo' & Dotty & $54.7 \%$ & $31.3 \%$ & $14.1 \%$ \\
& Vertically striped & 45.8 & 33.3 & 20.8 \\
& Broken line-like & 59.1 & 40.9 & - \\
& Wavy & - & - & 100.0 \\
& Vertical line-like & - & 17.9 & 82.1 \\
\hline \multirow{2}{*}{ 'Fuyu' } & Dotty & 67.5 & 17.5 & 15.0 \\
& Broken line-like & 50.0 & 50.0 & - \\
& Wavy & - & - & 100.0 \\
& Vertical line-like & - & 24.2 & 75.8 \\
& Cloudy & 100.0 & - & - \\
\hline
\end{tabular}

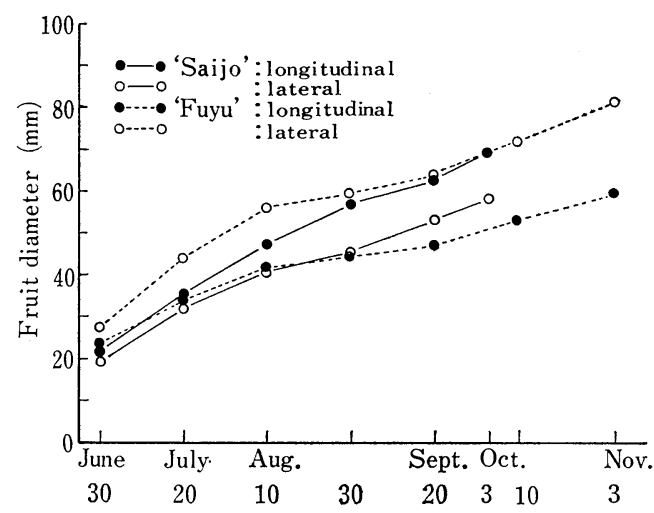

Fig. 3. Growth curves of fruits in 'Saijo' and 'Fuyu'.

The positions of these disorders on the fruit surface are shown in Table 1 . Broken linelike and cloudy types occurred mainly in the apical and median portions, and wavy and vertical line-like types were observed mostly in the basal portion.

The growth curves of 'Saijo' and 'Fuyu' fruits are shown in Fig.3. 'Fuyu' gave a double sigmoid curve involving two periods (until early August and after middle September) of rapid growth with a period (from early August to early September) of slow or suspended growth in between. 'Saijo' did not show such a distinctive period of slow growth, but maintained a relatively rapid growth rate until harvest time. It should be mentioned that at every date of measurement the transverse diameter was longer than the longitudinal one in 'Fuyu', while the reverse was noted in 'Saijo'.

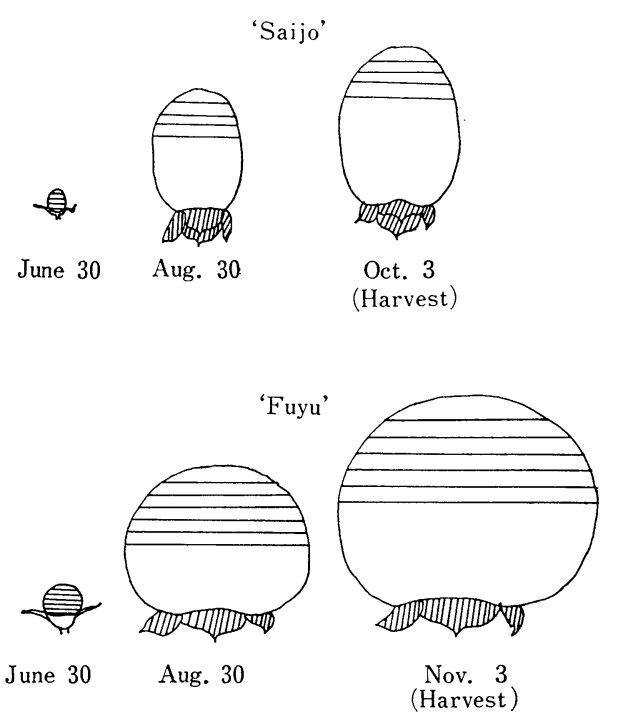

Fig.4. Scheme of lozalized fruit growth in 'Saijo' and 'Fuyu'. I. Latitudinal lines were marked by the tip of needle on June 30 on the surface of each fruit at $2 \mathrm{~mm}$ intervals from apex to base.

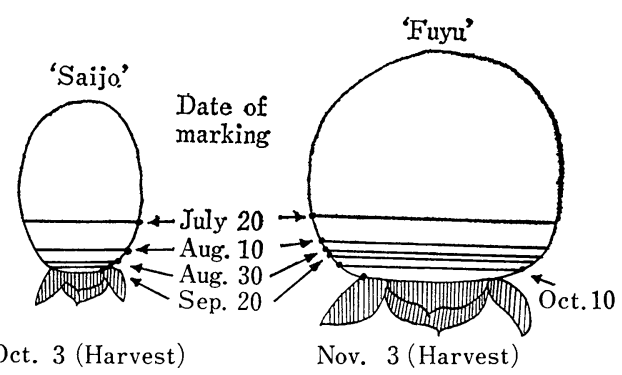

Fig.5. Scheme of localized fruit growth in 'Saijo' and 'Fuyu'. II. A latitudinal line was marked at the base of surface by the tip of needle every 20 days from Jnly 20 to each harvest.

A scheme of localized growth in the fruits of both cultivars is shown in Fig. 4. The latitudinal lines marked at the $2 \mathrm{~mm}$ intervals from the apex to the base on June 30 moved upward with fruit growth in both cultivars. As a result, the distance between calyx and the lowest line at harvest (more than 25 times the initial distance) was much greater than each of the intervals between the marked lines which were almost equal to each other and 3 to 5 times the initial distance. This fact clearly indicated that the growth rate of the basal portion was much higher than that of the median and apical ones. The growth of the basal portion was further examined by 
Table 2. Localized growth in the basal portion of fruit in 'Saijo' and 'Fuyu' as expressed by the intervals between the latitudinal lines at each harvest time. See the description in Fig.5.

\begin{tabular}{c|ccccc}
\hline Date & $7 / 20-8 / 10$ & $8 / 10-8 / 30$ & $8 / 30-9 / 20$ & $9 / 20-10 / 3$ & ('Saijo') \\
Cultivar & $7 / 20-8 / 10$ & $8 / 10-8 / 30$ & $8 / 30-9 / 20$ & $9 / 20-10 / 10$ & $10 / 10-11 / 3 \quad$ ('Fuyu') \\
\hline 'Saijo' & $9.5 \mathrm{~mm}$ & $4.4 \mathrm{~mm}$ & $2.1 \mathrm{~mm}$ & $1.6 \mathrm{~mm}$ & $\mathrm{~mm}$ \\
'Fuyu' & 8.2 & 3.2 & 2.0 & 3.1 & 4.0 \\
\hline
\end{tabular}
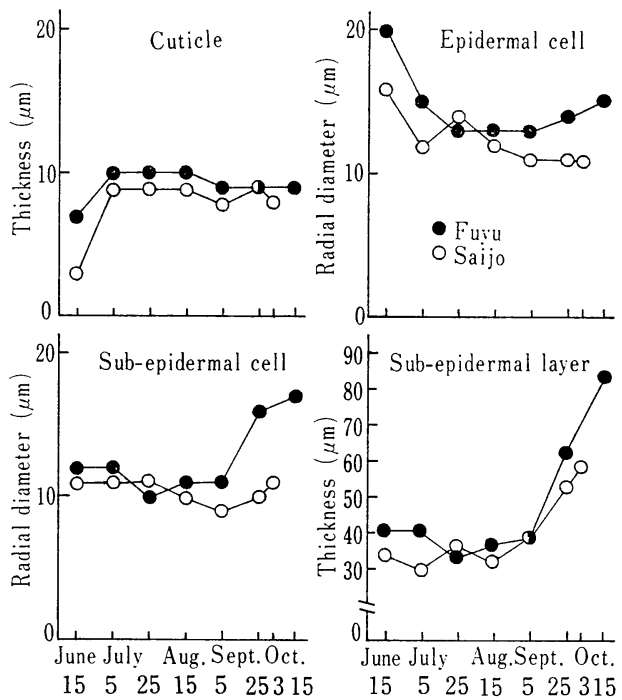

Fig.6. Seasonal changes in tissue thickness and cell size in radial direction of the fruit skin.

marking a latitudinal line at the base of the fruit surface every 20 days from July 20 to harvest as shown in Fig. 5. The distances between the lines were measured at harvest, Oct. 3 in 'Saijo' and Nov. 3 in 'Fuyu' and the data are shown in Table 2 . The rate of longitudinal growth around the basal portion was high in both cultivars from July 20 to Aug. 10 after which it decreased gradually. However, the rate markedly increased in 'Fuyu' alone from Sept. 20 to harvest, Nov. 3.

The fruit skin of persimmon consists of the cuticle, one layer of epidermal cells, and several layers of sub-epidermal cells and stone cells from the outside to the inside in this order. As shown in Fig.6, the cuticle layer in 'Fuyu' was twice as thick as that in 'Saijo' on June 15, about 10 days after full bloom. The thickness of the cuticle layer increased rapidly in both cultivars until July 5 , when the values were about $10 \mu \mathrm{m}$ in ' $\mathrm{Fuyu}$ ' and 8-9 $\mu \mathrm{m}$ in 'Saijo'. Thereafter the values did not change much up until each harvest time.

The radial diameter of epidermal cells in 'Fuyu' was the largest on June 15 (about 20 $\mu \mathrm{m})$, and then decreased rapidly until July 25. After a constant period from July 25 to Sept. 5, the diameters then increased gradually toward the harvest time. The radial diameter of epidermal cells in 'Saijo' measured on each of the dates except July 25 was several $\mu \mathrm{m}$ smaller than that in 'Fuyu' measured on the same date. The diameter was largest on June 15 (about $16 \mu \mathrm{m}$ ), the same as in 'Fuyu'.

Both cultivars showed an almost constant and similar value in both the radial diameter of sub-epidermal cells $(9-12 \mu \mathrm{m})$ and the thickness of this layer $(30-40 \mu \mathrm{m})$ until Sept. 5. After that time, either the diameter or the thickness tended to increase in both cultivars, but the rates of increase were much larger in 'Fuyu' than in 'Saijo'.

\section{Discussion}

Since 1963, when Yamashita et al. (11) reported the disorders occurring on the surface of 'Fuyu' fruits, collectively called black stain, their types and causes have been investigated in many local cultivars of Japanese persimmon $(2,3,4,9,10)$. 'Izu', 'Koshu hyakume' and 'Akagaki' have been shown to be very susceptible to them $(2,3)$. However, there is no data except ours on the susceptibility of 'Saijo' to black stain compared with that of other cultivars.

This study showed that at harvest 'Fuyu' did not differ from 'Saijo' in the total rate of occurrence of black stain. However, there were differences in the rate of occurrence of the various types. Dotty type occurred most frequently in both cultivars. In 'Fuyu' verti- 
cal line-like followed dotty in rate of occurrence, but neither markedly down-graded the market value of the fruit. In 'Saijo', however, vertically striped and broken line-like types followed dotty in rate of occurrence, and these types greatly reduced the marketability of fruit. This fact seems to be one of the important reasons why 'Saijo' is experientially recognized as a cultivar particularly susceptible to the disorders.

It has been suggested $(7,8,9)$ that dotty type is caused by fungus (Leptothrium pomi Sacc, Glomerella sp. and Alternaria sp.) or copper in Bordeaux mixture. Insects (thrips, such as Scirtothrips dorsalis Hood) or fungus (Botrytis cinerea Persoon) (9), have been suggested as the cause of wavy type disorders. Vertical line-like type is thought to be caused by some kind of mechanical injury; the corners of calyx scratch the surface of fruit during its growth and the scars develop into the black stain (9).

Two of the other types, vertically striped and broken line-like seem to relate mainly to the fruit enlargement itself. They are presumed to be the typical disorders caused by exposure of the epidermal and sub-epidermal cells to air as a result of the expansion of fine splits on the skin with fruit growth. The developed splits finally become black due to the oxidation of polyphenol substances in these cells(6). Chujo and Ashizawa(1) have observed by scanning electron microscopy many fine splits reaching the epidermal or sub-epidermal cells on the surface of black stain-free 'Fuyu' fruit sampled at harvest. They suggested that these fine splits may be the first step of broken line-like type. It seems that fewer splits may arise on the surface if fruit growth accompanies the successive development of the cuticle and epidermal cells until the late stage of growth. As shown in this paper, 'Saijo' did not undergo the distinctive period of slow growth which 'Fuyu' did, but kept up a relatively rapid increase in both the transverse and longitudinal diameters until harvest. However, the cuticle layers in both cultivars developed little after early July, and the radial size of epidermal cells in the later stage of fruit growth in
'Saijo' was remarkably inferior to that in 'Fuyu'. These results may be closely related to the fact that 'Saijo' was more susceptible to vertical striped and broken line-like types than 'Fuyu'.

In 'Saijo', the sutures of 4 carpels form the distinctive vertical grooves where the growth of skin tissues seems to be less active than at other areas. This may also be a cause of vertical striped type since the disorder usually appears at the grooves.

Further, it should be noted that both vertical striped and broken line-like types occurred mainly at the apical and median portions of fruit. According to our observation on fruit growth, the meristematic activity remained longer at the basal portion of fruit than at the median and apical ones in both the persimmon cultivars, just as in egg-plant(5). It seems that the prolonged activity restrains the development of fine splits on skin at the basal portion and this is a reason for the localized occurrence of these disorders.

\section{Literature Cited}

1. Chuso, T. and M. Ashizawa. 1978. Ultrastructure of fruit surface of kaki (Diospyros kaki LINN. f.) observed by a scanning electron microscope. Tech. Bull. Fac. Agr. Kagawa Univ. 21:34-39. (In Japanese with English summary)

2. Hamachi, F., M. Tsuneto and A. Morita. 1974. Causes and control of black stain on the fruit skin of Japanese persimmon. I. Agr. and Hort. $49: 533$ - 536. (In Japanese)

3. Hamachi, F., M. Tsuneto and A. Morita. 1974. Causes and control of black stain on the fruit skin of Japanese persimmon. II. Agr. and Hort. $49: 653-655$. (In Japanese)

4. Isoda, R. 1979. Cause of a certain physiological disorder 'kokuhen-ka' of 'Saijo' persimmon (Diospyros kaki L.). Studies from Inst. Hort. Kyoto Univ. $9: 36-40$. (In Japanese with English summary)

5. Kano, K., T. Fujimura, T. Hirose and Y. Tsuкамото. 1957. Studies on the thickening growth of garden fruits I. On the cushaw, egg-plant and pepper. Memoirs Res. Inst. Food Sci. Kyoto Univ. 12:45-90.

6. Kitagawn, H. 1970. Cultivation and utilization of Japanese persimmons p. 141-143. Yokendo, Tokyo. (In Japanese)

7. Noguchi, Y. 1981. Studies on the rind stain 
of persimmon fruits III. On the infection season and main infection period of persimmon fruits rind stain, and relation between anthracnose and its rind stain. Bull. Fukuoka Hort. Exp. Sta. 19 : 60-65. (In Japanese with English summary)

8. Oda, M. and T. Kodama. 1979. Developmental and ecological studies of persimmon fruit's stain-like symptoms caused by coletotrichum spp. and some other fungi. Bull. Nara Agr. Exp. Sta. 10 : 53-63. (In Japanese with English summary)

9. Watanabe, S. 1973. Studies on the cause of injury in surface of tree and vegetable fruit
(4). Soiled injury of surface in 'Hiratanenashi' persimmon fruit. Jour. Yamagata Agr. For. Soc. $30: 62-69$. (In Japanese with English summary)

10. Yamamura, H., Y. Fukuhara and R. Naito. 1981. Symptoms and causes of black spots in the fruit skin of 'Saijo' Japanese persimmon. Bull. Fac. Agr. Shimane Univ. 15:22-30. (In Japanese with English summary)

11. Yamashita, T., H. UENo and M. IshizaKi. 1963. Black stain in Japanese persimmon (cv. Fuyu) fruits. Abst. Japan Soc. Hort. Sci. Autumn Meet. 1963. 5. (In Japanese)

\section{カキにおける黒変污損果の発生と果実の肥大並びに果皮組織発達との関係}

山村 宏・別所英男 - 内藤隆次

島根大学農学部 690 松江市西川津町 1060

\footnotetext{
摘 要

“西条’の果皮に黒変污損が発生しやすいといわれる原 因を明らかにするために，カキ ‘西条”と ‘富有”両品種 の黒変污損果発生々果実の肥大, 果皮組織発達々の関係 を調查した.

1. 両品種とも点状污損の発生率が最も高かったが, “西条”では点状污損に次いで溝状, 緃線状, 破線状污損 が多かった. “富有”では点状及び縦線状污損が大部分 で, 他の症状は概して少なかった。

2. 破線状及び雲形状污損は赤道部から果頂部にかけ

て発生が多く, 波状及び縦線状污損は果実基部に発生が 多かった.

3. 両品種とも果実の発育は部位によって異なり, 果 頂部に近い部位注ど生長は次第に鈍化した.

4. “西条’ は幼果時のクチクラ層が “富有” 比べ薄 く, 表皮細胞や亜表皮細胞の発達も“富有”より劣った.

5. “西条’で発生の多い溝状及び破線状污損は, 果実 発育後期の急激な果実肥大に伴って, 果面上の微細な亀 裂の裂開が原因となる典型的な症状と考えられた。
} 